\title{
TOURIST PERCEPTION OF TANJUNG DURIAT ECOTOURISM JATIGEDE RESERVOIR AREA SUMEDANG REGENCY
}

\author{
Naufal Algiffary, Endah Djuwendah \\ Universitas Padjadjaran \\ naufalgiffary@gmail.com
}

\begin{abstract}
Jatigede Reservoir has eight attractive tourism potential to be visited by tourists who want to vacation in Sumedang Regency. One of the tourist attractions in the Jatigede Reservoir area that is often visited by tourists is Tanjung Duriat. In 2018 tourists visiting Tanjung Duriat experienced a drastic decline. The purpose of this study was to determine the perceptions of tourists visiting the Tanjung Duriat Tourism Center to be a material consideration to improve the quality of tourism facilities and increase the number of tourists coming. The design used is quantitative. The results of the study showed that most tourists from Tanjung Duriat Tourism came from outside the Sumedang Regency, male sex between the ages of 20-29 years with education. The graduate worked as an employee and had income above Rp. 3,000,000.00. Most of the visitors who come to Tanjung Duriat Tourism Center for vacation because this place is interesting to visit and the ticket price for admission is moderate, which means it is not expensive or not cheap. Most visitors budget for recreation costs to come to Tanjung Duriat Tourism Center below than Rp. 200,000.00. Almost all visitors who come with family use their transportation. Most visitors come to Tanjung Duriat Tourism Center for the first time and are interested in visiting again. The visitor's perception of the Tanjung Duriat Tourism Wana object can be concluded well. Although the tourists were unhappy with the road conditions that were considered harmful, the perceptions of the tourists towards the entire Wana Wisata object were considered good so that they could cover up the shortcomings.
\end{abstract}

Keywords: Jatigede Reservoir, Ecotourism, Tourist Perception

\section{INTRODUCTION}

The tourism sector provides substantial foreign exchange to the country. Indonesia realizes the importance of the tourism sector to the economy because tourism growth always over Indonesia's economic growth (Soebagyo, 2012).

In 2017, the tourism sector was the 2nd largest foreign exchange contributor with a value of 190 trillion rupiahs. Indonesia's natural beauty and cultural richness can be the potential to be developed in the tourism sector. Biological natural resources and their ecosystems, the diversity of flora fauna and natural phenomena with the beauty of pristine scenery can be the attraction of a tourist attraction. 
West Java is one of the provinces in Indonesia that has enormous potential for tourism development. The advantage owned by West Java is a rural environment with very friendly with Sundanese,

A strategic geographical location has a beautiful natural panorama and abundant resources. The shifting concept of tourism world through particular tourist interest or known as Wana Wisata. Wana Wisata can be an excellent opportunity for our country with this remarkable natural potential. This is due to the number of tourists who tend to prefer to visit tourism objects that are nature-based.

Wana Wisata is a natural or artificial tourism place that exists in a particular area that is maintained and cared for educational and tourism purposes, so it is a pleasure for tourists who visit. Wana tourism is also a tourism object developed and built to attract as many tourists as possible without changing the function of the tourist attraction.

Sumedang Regency has a great potential to develop the Wana Wisata. The construction of the Jatigede Reservoir provides an excellent possibility for tourism development in Sumedang district. Jatigede Reservoir has a beautiful panorama of natural beauty and can be a tourist attraction for domestic or foreign tourists to see the beautiful scenery there. So it becomes a business opportunity that can be utilized in the tourism sector.

The tourist attraction in the Jatigede Reservoir area which is often visited by tourists is Tanjung Duriat. Tanjung Duriat is located on the northwest coast of Jatigede Reservoir Dam, precisely in Pejagan village of Cisitu subdistrict. Duriat Cape is managed by Perum Perhutani Sumedang and LMDH village Pajagan. So the development of Tanjung Duriat tourism object can benefit the surrounding society.

Tourists visiting the Wana Wisata Tanjung Duriat in 2018 have decreased from the previous year of 17,284 tourists. To observe this, the manager of Tanjung Duriat Tourism service needs to know the assessment of the tourists who come in the form of perception of tourists to the attraction. Based on this case, it is necessary to research to know the tourist destinations in the visit, then the perception of tourists to the object of Wana Wisata Tanjung Duriat, whether to be maintained or developed. How do visitors impress the service they get there when they visit.

\section{Perception}

\section{LITERATURE REVIEW}

Bimo Walgito (2002) reveals that perception is a process of organizing, interpretation of stimulus received by organisms or individuals so that it is something meaningful, and an integrated activity in Individual self. Individuals can take responsibility as a result of perception with a variety of forms. Which Stimulus will get the reaction of the individual depends on the attention of the individual concerned. Based on this case, the feelings, the ability of thinking, the experiences of individuals are not the same, so in the conception of a stimulus, the outcome of perception may differ between individuals and other individuals.

\section{Wana Wisata}

Wana Wisata is a natural tourist attraction that is located in a protected forest or production forest, which belongs to the area Perhutani (Perhutani 2013). Based 
on activities, Wana Wisata developed by PT. Perhutani divided into two kinds, the following are:

1) Overnight Wana Wisata, place to stay or overnight, for example, campground.

2) Not overnight Wana Wisata (day recreation), open field with just facilities, including picnic benches.

The development pattern of Wana Wisata by PT. Perhutani, as follow:

1) The development of recreational objects should be as simple as possible and cultivated to maintain its original form and state.

2) The type of recreation that is constructed can fulfill various motivations and can be reached by the weak Economic community.

3) Recreation objects contain aspects of recreation, education (natural love coaching), and sports.

Except for two kinds of Wana Wisata activities that are overnight and not overnight tours, the place can be completed with activities such as:

1) Crosswalk, which is as wide as $\pm 2 \mathrm{~m}$ for the not tricky step so that people can walk casually for approximately 1.5 hours.

2) Beautiful cross-forest, walking trails are provided with the aim of enjoying, studying, and reviewing the natural conditions, forest phenomena, flora and fauna, and so on that are located on left paths and forests.

3) Animal Breeding.

4) Hazard protection, e.g., gaps and landslides

5) Education.

\section{Characteristics and Tourists Perception}

According to Wahab (1992), characteristics are used to measure the segmentation of tourists such as age, gender, income, occupation, educational background, and others. Characteristics of tourists can determine the image of the destination.

According to Yoeti (2006), Tourists characteristics include age, gender, level of education, and occupation. Age and gender are variables that are often used in the field of tourism to determine market share because it is a representative variable that determines the interest and motivation of a person to travel. Education shows the level of knowledge owned by tourists as well as the information it has. Tourists know information about the essential recreation objects, so it can be known that the place can satisfy its needs. The job can affect lifestyle, related to leisure and economic resources ability to travel trip.

According to Warpani (2007), the perception of tourists is a rating or traveler's view of a tourist attraction. A tourist attraction should improve the quality of the object for a better positive perception. The world of tourism is a traveler's opinion or viewpoint in understanding a tourist destination. In the tourism industry, every traveler has their personality, so because of the real phenomena, they have their respective perceptions. The perception of tourists is one of the important things in the development of a tourism destination. About what you are interested in, desired, and expected to be a destination is very important means in relation to the marketing of the attraction. The perception of tourists includes services provided, facilities and infrastructures provided, and accessibility to the tourist place. 


\section{METHODOLOGY}

This research object is the perception of tourists towards Tanjung Duriat, which is located in the area around Jatigede Reservoir, Kab. Sumedang. The research venue is done intentionally (purposive) with the consideration of Tanjung Duriat will be developed by Perhutani and local society into a natural based tourism object in Jatigede Reservoir area. The research design used is quantitative descriptive, and the technique of research used is the survey technique.

The data collection techniques are important things that become a connector between researchers and the research objects and then generate the data. The technique used in this research is to collect data; that is:

1. Observation

2. Further Interviews

3. Documentation Research

4. Questionnaire

According to Miles and Huberman (in Satori and Komariah, 2017), the stages of processing and analyzing data in qualitative research, are:

1. Data Reduction

2. Data display

3. Conclusion Drawing / Verification

\section{RESULTS AND DISCUSSION \\ General Description of Tanjung Duriat Ecotourism}

Tanjung Duriat ecotourism in a forest area of 6.3 ha is located in Pajagan Village, Cisitu District, Sumedang Regency. Pagajan Village is at 411 meters heights above sea level. This ecotourism operates every day from $08.00 \mathrm{WIB}$ to 16.00 WIB. The price of this ecotourism entrance ticket is IDR 10,000 / person.

The meaning of Tanjung Duriat is Tanjung Cinta. This thing is closely related to the location where it placed, which is a hill that in the side of Jatigede Reservoir. Then the term Duriat is taken from Sundanese, which represents love. However, love here is not just describing affection.

Three parties manage ecotourism, that is Perhutani Forest Management Unit (KPH) Sumedang, together with the Pajagan Village Forest Society Institute (LMDH) and the investors from CV. Campernik Sumedang. These parties have a profit-sharing system that based on the agreement stated in the cooperation agreement of $50 \%$ for investors, $40 \%$ for Perhutani, and 10\% for LMDH.

\section{The Tourists Perception to Wana Wisata Tanjung Duriat}

The tourist's perception of Wana Wisata object Tanjung Duriat is divided into four categories: service, infrastructure, ground conditions, and preservation of Wana Wisata. Each of these categories is divided into several questions that are already available in the questionnaire about the individual's perception.

The service category is more focused on the manager or employees who are directly related to tourists with the indicator that is the delivery of information that is easy to understand, the hospitality of the officer, the attendant, and politeness officers. The second category is facilities and infrastructures with indicators: toilets, musholla, garbage, parking lot, shelter/saung, food stalls, and view decks. The third category is the condition of surroundings with the indicator is Road condition, air 
area, cleanliness, comfort, the beauty of Wana Wisata, and arrangement of Wana Wisata. Moreover, the fourth category is the preservation of Wana Wisata with the indicator is: planting trees, the existence of stalls, garbage/waste, and damage to natural objects.

\section{Perception to Service}

Table 1. Perception to Service

\begin{tabular}{|c|c|c|c|c|c|c|c|c|}
\hline \multirow{3}{*}{ No } & \multirow{3}{*}{ Indicator } & \multicolumn{6}{|c|}{ Criteria } & \multirow{3}{*}{$\begin{array}{l}\text { Score } \\
\text { Total }\end{array}$} \\
\hline & & \multicolumn{2}{|c|}{ Not Agree } & \multicolumn{2}{|c|}{ Agree } & \multicolumn{2}{|c|}{ Very Agree } & \\
\hline & & Total & Score & Total & Score & Total & Score & \\
\hline 1 & $\begin{array}{ll}\text { Information } & \\
\text { delivery } & \text { is } \\
\text { easy } & \text { to } \\
\text { understand } & \\
\end{array}$ & 15 & 1 & 75 & 2 & 10 & 3 & 195 \\
\hline 2 & Friendly staff & 18 & 1 & 73 & 2 & 9 & 3 & 191 \\
\hline 3 & Sprightly staff & 25 & 1 & 71 & 2 & 9 & 3 & 194 \\
\hline 4 & Polite staff & 16 & 1 & 76 & 2 & 8 & 3 & 192 \\
\hline & Total & \multicolumn{2}{|c|}{74} & \multicolumn{2}{|c|}{590} & \multicolumn{2}{|c|}{108} & 772 \\
\hline \multicolumn{2}{|c|}{ Percentace $(\%)$} & \multicolumn{2}{|c|}{9,6} & \multicolumn{2}{|c|}{76,4} & \multicolumn{2}{|c|}{14} & 100 \\
\hline
\end{tabular}

Index of Minimum Value

Index of Minimum Value $=$ Minimum Score $\times \sum$ Questions $\times$ Respondents

$$
\begin{aligned}
& =1 \times 4 \times 100 \\
& =4000
\end{aligned}
$$

Index of Maximum Value $=$ Maximum Score $\times \sum$ Questions $\times \sum$ Respondents

$$
\begin{aligned}
& =3 \times 4 \times 100 \\
& =1200
\end{aligned}
$$

Interval $=\frac{\sum \text { Questions }(\text { maximum score-minimum score })}{\sum \text { Category }} \times \sum$ Respondents

$$
\begin{aligned}
& =\frac{4 \times(3-1)}{3} \times 100 \\
& =266,67
\end{aligned}
$$

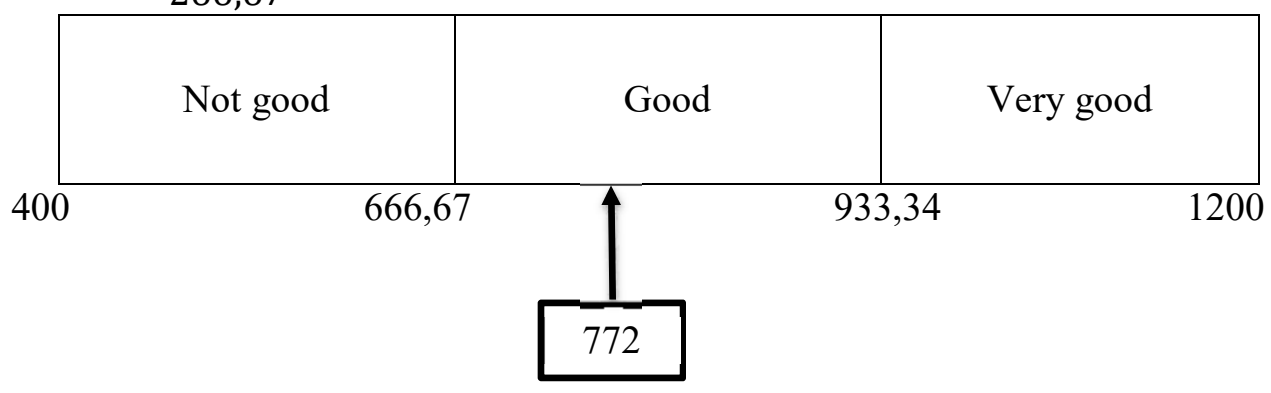

The service provided by the management of Tanjung Duriat Wana Wisata to consumers in the perception or good rating by the tourists is 772 , in the prove with 
the processing of several indicators of questions such as information that is carefree understandable, friendly attitude and polite in providing services to tourists if anyone needs. For example, location issues and road directions if you want to get to the tree Tower/Viewdeck. Perception of tourists is already in a good position but the number obtained is less satisfactory, this is due to sometimes tourists are not at all informed about the facilities that are already available in the Wana Wisata.

In this place, no sketch or map can show the location of the facilities that have been available so that tourists come to be confused when inside the area. Usually, travelers use a sketch to estimate the time they will use in traveled at Wana Wisata.

According to the results of interviews with respondents, ticket keepers are sometimes not as comfortable in serving and providing information to tourists who come in so that they are not satisfied with the staff's alacrity. Although sometimes it is not sprightly, the ticket office is amiable and polite in welcoming tourists who come. Their reception is very polite because of the friendly Sundanese people who engage in daily interaction

\section{Perception of Facilities and Infrastructure}

Table 2. Perception of Facilities and Infrastructure

\begin{tabular}{|c|c|c|c|c|c|c|c|c|}
\hline \multirow{3}{*}{ No } & \multirow{3}{*}{ Indicator } & \multicolumn{6}{|c|}{ Criteria } & \multirow{3}{*}{$\begin{array}{l}\text { Score } \\
\text { Total }\end{array}$} \\
\hline & & \multicolumn{2}{|c|}{ Not Agree } & \multicolumn{2}{|c|}{ Agree } & \multicolumn{2}{|c|}{ Very Agree } & \\
\hline & & Total & Score & Total & Score & Total & Score & \\
\hline 1 & Toilet & 14 & 1 & 77 & 2 & 9 & 3 & 195 \\
\hline 2 & Musholla & 22 & 1 & 71 & 2 & 7 & 3 & 185 \\
\hline 3 & $\begin{array}{l}\text { Camping } \\
\text { Ground }\end{array}$ & 38 & 1 & 55 & 2 & 7 & 3 & 169 \\
\hline 4 & Park Area & 11 & 1 & 79 & 2 & 10 & 3 & 199 \\
\hline 5 & Shelter/Saung & 23 & 1 & 60 & 2 & 17 & 3 & 194 \\
\hline 6 & Viewdeck & 13 & 1 & 75 & 2 & 12 & 3 & 199 \\
\hline 7 & Food stalls & 23 & 1 & 70 & 2 & 7 & 3 & 184 \\
\hline & Total & \multicolumn{2}{|c|}{144} & \multicolumn{2}{|c|}{974} & \multicolumn{2}{|c|}{207} & 1325 \\
\hline \multicolumn{2}{|c|}{ Percentace $(\%)$} & \multicolumn{2}{|c|}{10,9} & \multicolumn{2}{|c|}{73,5} & \multicolumn{2}{|c|}{15,6} & 100 \\
\hline
\end{tabular}

Index of Minimum Value $=$ Minimum Score $\times \sum$ Questions $\times$ Respondents

$$
\begin{aligned}
& =1 \times 7 \times 100 \\
& =700
\end{aligned}
$$

Index of Maximum Value $=$ Maximum Score $\times \sum$ Questions $\times \sum$ Respondents

$$
\begin{aligned}
& =3 \times 7 \times 100 \\
& =2100
\end{aligned}
$$

Interval

$$
\begin{aligned}
& =\frac{\sum \text { Questions (maximum score-minimum score) }}{\sum \text { Category }} \times \sum \text { Respondents } \\
& =\frac{7 \times(3-1)}{3} \times 100 \\
& =466,67
\end{aligned}
$$




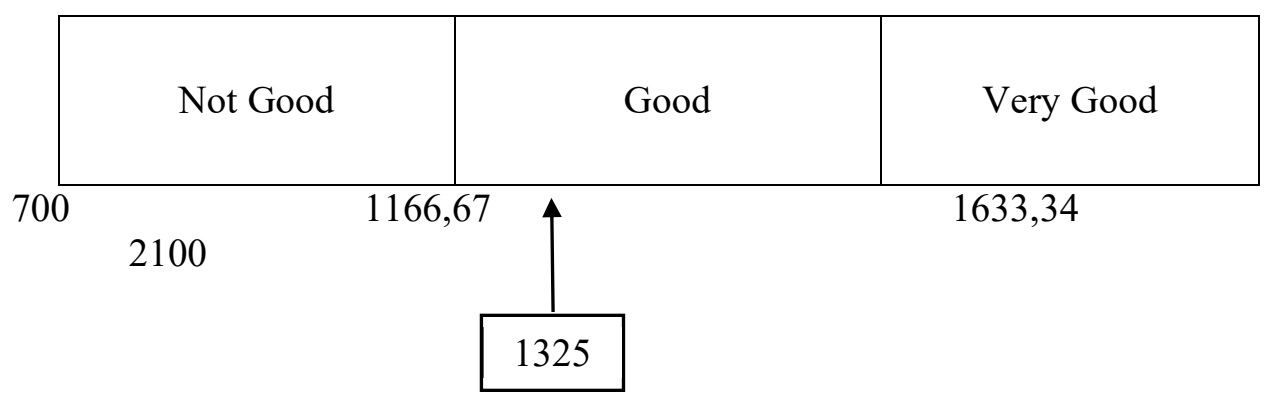

The perception of facilities and infrastructures found in the Tanjung Duriat Wana Wisata has a different value from tourists. Based on the analysis with a count of the index of minimum value of 700 and the index of the maximum value of 2100 with an interval range of 466.67 , it is obtained by the count of perception of tourists to facilities and infrastructure is around 1,325 . So, the availability of facilities and infrastructure can be perceived well.

According to essential information in the field, Wana Wisata Tanjung Duriat also provides camping and fishing area for the tourists who come. However, currently, there is no rental of camping gear and fishing equipment so tourists must bring their own. To date, there have never been tourists who are camping and fishing. Because of the lack of information about activities that can be done by tourists in the Wana Wisata Tanjung Duriat, there are rarely tourists who fish in the Jatigede reservoir. When the wind is not too tight, tourists can boat in the Jatigede reservoir for IDR 20,000/person on weekdays and IDR 25,000/person on public holidays

\section{Perception of Wana Wisata Environment}

Table 3... Perception of Wana Wisata Environment

\begin{tabular}{|c|c|c|c|c|c|c|c|c|}
\hline \multirow{3}{*}{ No } & \multirow{3}{*}{ Indicator } & \multicolumn{6}{|c|}{ Criteria } & \multirow{3}{*}{$\begin{array}{c}\text { Scor } \\
\text { e } \\
\text { Total }\end{array}$} \\
\hline & & \multicolumn{2}{|c|}{ Not Agree } & \multicolumn{2}{|c|}{ Agree } & \multicolumn{2}{|c|}{ Very Agree } & \\
\hline & & Total & $\begin{array}{c}\text { Scor } \\
\mathrm{e}\end{array}$ & Total & $\begin{array}{c}\text { Scor } \\
\text { e }\end{array}$ & Total & $\begin{array}{c}\text { Scor } \\
\text { e }\end{array}$ & \\
\hline 1 & Road conditions & 95 & 1 & 5 & 2 & 0 & 3 & 105 \\
\hline 2 & Ambient air & 13 & 1 & 77 & 2 & 10 & 3 & 197 \\
\hline 3 & $\begin{array}{l}\text { Hygiene Wana } \\
\text { Wisata }\end{array}$ & 15 & 1 & 80 & 2 & 5 & 3 & 190 \\
\hline 4 & $\begin{array}{ll}\text { Comfort } & \text { Wana } \\
\text { Wisata } & \\
\end{array}$ & 24 & 1 & 71 & 2 & 5 & 3 & 181 \\
\hline 5 & Beautiful view & 8 & 1 & 70 & 2 & 22 & 3 & 214 \\
\hline 6 & $\begin{array}{l}\text { Arrangement } \\
\text { Wana Wisata }\end{array}$ & 35 & 1 & 61 & 2 & 4 & 3 & 169 \\
\hline
\end{tabular}




\begin{tabular}{|c|c|c|c|c|}
\hline Total & 190 & 728 & 138 & 1056 \\
\hline Percentace $(\%)$ & 18 & 68,9 & 13,1 & 100 \\
\hline
\end{tabular}

$$
\begin{aligned}
& \text { Index of Minimum Value }=\text { Minimum Score } \times \sum \text { Questions } \times \text { Respondents } \\
& =1 \times 6 \times 100 \\
& =600 \\
& \text { Index of Maximum Value }=\text { Maximum Score } \times \sum \text { Questions } \times \sum \text { Respondents } \\
& =3 \times 6 \times 100100 \\
& =1800 \\
& \text { Interval } \quad=\frac{\sum \text { Questions (maximum score-minimum score) }}{\sum \text { Category }} \times \sum \text { Respondents } \\
& =\frac{6 \times(3-1)}{3} \times 100 \\
& =400
\end{aligned}
$$

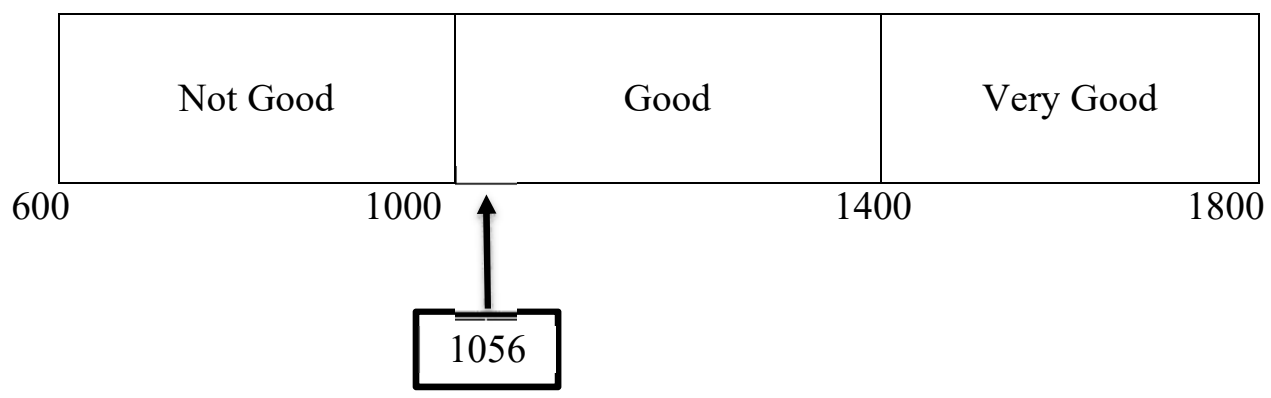

The perception of the wana wisata of Tanjung Duriat is a different value from tourists. Based on the analysis of researchers with a count of the minimum index value of 600 and the maximum index value of 1800 with an interval range of 400 , it is obtained by the count of perception of tourists on facilities and infrastructure is 1056 . Perception of facilities and infrastructure can be perceived either because it does not touch the number 1000. The figure is almost not good because the road condition to Tanjung Duriat is so bad that it is disliked by tourists who come and it gets a small number.

\begin{tabular}{|c|c|c|c|c|c|}
\hline \multirow{2}{*}{ No } & \multirow{2}{*}{ Indicator } & \multicolumn{3}{|c|}{ Criteria } & \multirow{2}{*}{$\begin{array}{l}\text { Score } \\
\text { Total }\end{array}$} \\
\hline & & Not Agree & Agree & Very Agree & \\
\hline
\end{tabular}

All tourists are complaining about the road conditions with many rocks and roads that are buried with the ground: in the rainy season, the dirt road made of rain becomes damaged and perforated. The emergence of water puddle causes the road condition to become muddy. After the rain, the muds became a hole. It happened when tourists passed the main road to Tanjung Duriat. It is the main factor of the obstacles that come to Tanjung Duriat.

\section{Perception of Wana Wisata Preservation}

Table 4. Perception of Wana Wisata Preservation 


\begin{tabular}{|l|l|c|c|c|c|c|c|c|}
\hline & Total & Score & Total & Score & Total & Score & \\
\hline 1 & Planting trees & 13 & 1 & 80 & 2 & 7 & 3 & 194 \\
\hline 2 & Food stalls & 16 & 1 & 77 & 2 & 7 & 3 & 191 \\
\hline 3 & Waste & 20 & 1 & 75 & 2 & 5 & 3 & 185 \\
\hline 4 & $\begin{array}{l}\text { Damage to natural } \\
\text { objects }\end{array}$ & 15 & 1 & 80 & 2 & 5 & 3 & 190 \\
\hline & \multicolumn{1}{|c|}{ Total } & \multicolumn{2}{|c|}{64} & 624 & & 72 & 760 \\
\hline
\end{tabular}

Index of Minimum Value $=$ Minimum Score $\times \sum$ Questions $\times$ Respondents

$$
\begin{aligned}
& =1 \times 4 \times 100 \\
& =400
\end{aligned}
$$

Index of Maximum Value $=$ Maximum Score $\times \sum$ Questions $\times \sum$ Respondents

$$
\begin{aligned}
& =3 \times 4 \times 100 \\
& =1200
\end{aligned}
$$

Interval $=\frac{\sum \text { Questions (maximum score-minimum score) }}{\sum \text { Category }} \times \sum$ Respondents

$$
\begin{aligned}
& =\frac{4 \times(3-1)}{3} \times 100 \\
& =266,67
\end{aligned}
$$

\begin{tabular}{|c|c|cr|}
\hline Not Good & & Good & \multicolumn{2}{c|}{ Very Good } \\
\hline $400 \quad 666,67$ & $\uparrow$ & 933,34 & 1200 \\
& & & \\
& & & \\
\hline 760 & &
\end{tabular}

Preservation of Tanjung Duriat tourism has a different value from tourists. Based on the analysis of researchers with a count of the minimum index value of 400 and the maximum index value of 1200 with an interval range of 266.67 , it is gained a count of perception of tourists on the preservation of Tanjung Duriat tourist Wana is of 760. The preservation of the environment carried out in Wana Wisata Tanjung Duriat can be perceived as well because it does not touch the number 666.67.

According to the tourists who come, the placement and availability of garbage in the Wana Wisata of Tanjung Duriat are not good. The tourists hope that the trash can be placed alongside the Saung/shelter, so tourists easily throw the 
garbage in place after eating. Damage to natural objects can be said to be safe because there are almost no streaks and damage to trees and rocks.

Table. 14 Disadvantages of Wana Wisata by tourists

\begin{tabular}{|l|l|}
\hline Indicator & \multicolumn{1}{|c|}{ Disadvantages/Complaints (-) } \\
\hline Service & $\begin{array}{l}\text { (-) Ticket keepers sometimes forget to provide information } \\
\text { about the facilities in Tanjung Duriat } \\
\text { (-) Ticket keepers are sometimes not as attentive in serving } \\
\text { the coming visitors }\end{array}$ \\
\hline $\begin{array}{l}\text { Facilities and } \\
\text { Infrastructure }\end{array}$ & $\begin{array}{l}\text { (-) Less information about the camp area } \\
\text { (-) There is no location sketch in the tourism place } \\
\text { (-) Water shortage problems for tourists who come }\end{array}$ \\
\hline $\begin{array}{l}\text { The } \\
\text { environment of } \\
\text { Wana Wisata }\end{array}$ & $\begin{array}{l}\text { (-) The road traveled to the Wana Wisata is not worth a pass } \\
\text { (-) Lack of directions on some streets } \\
\text { (-) Lack of lighting along the way to Duriat Cape }\end{array}$ \\
\hline $\begin{array}{l}\text { Preservation of } \\
\text { Wana Wisata }\end{array}$ & $\begin{array}{l}\text { (-) Ineffective trash placement } \\
\text { (-) Number of waste bins is not much }\end{array}$ \\
\hline
\end{tabular}

\section{CONCLUSION}

1. Based on the detailed analysis result of tourist characteristics Tanjung Duriat Wana Wisata mostly come from outside the district Sumedang, they are malegender aged between $20-29$ years with Bachelor's education as an employee and has revenue above Rp 3,000,000.00. Most of the tourists who come to Tanjung Duriat Wana Wisata for a vacation because this place is exciting to visit and the price of entry is medium, which means it is not expensive or not cheap. Most tourists estimate the cost of recreation to come to Tanjung Duriat Wana Wisata below from Rp 200,000.00. Almost all tourists come with their family by using their transportation. Most of the tourists come to Tanjung Duriat Wana Wisata for the first time and are interested in visiting again.

2. The tourist's perception of Tanjung Duriat tourism is concluded to be good overall. Although the tourists are not happy about the road condition that is poorly assessed the tourist's perception of the overall Wana Wisata object is well evaluated so it can cover the drawback.

\section{SUGGESTION}

The advice that can be given to the officers about of the Tanjung Duriat Wana Wisata, the below:

1. Managers need to do some things, including:

a. Repair the road to Tanjung Duriat Wana Wisata.

b. I am adding directions in several road segments, especially highways and roads that connect the area of Pakualam village and Sumedang district with other regions.

c. Adding lighting along the road to Tanjung Duriat

d. Adding Trash in every shelter

e. Adding location scetch inside Wana Wisata 
f. Repairing the water facilities so that tourists feel comfortable to be in the tourist area.

g. The ticket keeper must provide instructions on the facilities there to the tourists who are coming

2. The local government can continue to increase the number of tourist places around the Jatigede Reservoir, one of the ways is to observe on each potential territory to be developed into a tourism place then facilitate society, and build facilities and infrastructures that support the area of tourist object.

\section{REFERENCE}

Bimo Walgito. 2002. Pengantar Psikologi Umum. Yogyakarta: Andi Offset

Damanik, Janianton, dan weber, Helmut. (2006). Perencanaan Ekowisata Dari Teori ke Aplikasi. Yogyakarta: PUSPAR UGM dan Andi

Djuwendah, E., Hapsari, H., Deliana, Y., \& Suartapradja, O. S. 2017. Potensi Ekowisata Berbasi Sumberdaya Lokal di Kawasan Waduk Jatigede Kabupaten Sumedang. Jurnal Paspalum UNWIM Vol. 5 No. 2.

Mihtah, Toha (2003). Perilaku Organisasi Konsep Dasar dan Aplikasinya. Jakarta: PT Raja Grafindo Persada

Nurjaya, M. M. 2018. Dampak Agrowisata Giri Tirta Kahuripan Terhadap Aspek Ekonomi, Sosial, dan Budaya Masyarakat. Skripsi. Jurusan Agribisnis Fakultas Pertanian. Universitas Padjadjaran.

Osman Ananti. 2017. Persepsi Wisatawan pada Objek Wisata Danau Buatan Kota Pekanbaru. Unpad. Bandung

[Perhutani].2013. Pariwisata Alam. http://www.perumperhutani.com//.[internet]

Salah Wahab. 1992. Manajemen Kepariwisataan. Penerbit Pradnya Paramita. Jakarta.

Soebagyo. 2012. Strategi Pengembangan Pariwisata di Indonesia. Jurnal Universitas Pancasila, Jakarta Selatan.

Sugiyono. 2013. Metode Penelitian Kuantitatif, Kualitatif dan R\&D. Jakarta: Alfabet.

Sunaryo. 2004. Psikologi Untuk Keperawatan. Jakarta: EGC

[TIES] The International Ecotourism Society. 2015. What is Ecotourism? [internet] https:// www.ecotourism.org /what-is-ecotourism.

Warpani ,Suwardjoko P dan Warpani, Indira P.2007. Pariwisata Dalam Tata Ruang Wilayah. ITB. Bandung.

Yoeti HDA et al. 2006. Pariwisata Budaya : Masalah dan Solusinya. Jakarta : Pradnya Paramita. 